\title{
Encompassing Objectivity-Desideratum to Tone Pedagogy in History to the aeon; with special reference to India
}

\author{
Agney G K \\ Mar Thoma College, M G University, Thiruvalla, Kerala, India. \\ Email: gkagni@gmail.com
}

Keywords: Pedagogy, Objectivity, History.

\begin{abstract}
This paper is conceived as an archetype of how pedagogy in history should undergo a paradigmatic shift and should reinvent itself by embarking an odyssey towards objectivity. History is often deliberated as a discipline that has the potential to overhaul the perceptions we hold towards our present and future. History by its very stature and holding should be deemed as threatening, to a person, society and all its amplified versions, once perverted. This work intends to showcase the alarming trends an instructor in history should be concerned about and how these trends should be kept at arm's length to expedite the imparting of non coloured history in our campuses.
\end{abstract}

\section{Status Quo}

Edification method, or its heavier jargonised lexeme- pedagogy, frustrates exhaustive definitions. This unquantifiable whole is the potent bedrock on which the subsequent generations is to be schooled in his attributes, attitudes and world view. The intellectual leanings of the guide as well as that of the frame provided by the educational programme occupy a central role in the development of ideological predilections of an upcoming generation. To be reasonable, in such a garb, one should be endowed with uncorrupted notions and understandings. He should be furnished with cognitive abilities to develop well composed perceptions, after assaying the provided nittygritties, realities and footings. But the prevalent prototype of pedagogy in the gospel of history actualised everything but the aforementioned desired results. This paper argues in favour of ushering a paradigmatic shift in instructing students- from school up to universities- in the discipline of history.

\section{The Proto type}

History in schools is traditionally informed as a 'story'; a chronological sequence of events, occurrences and personalities. Indeed, the predicament of colleges and universities are not diverse. The hardship has more to do with the principles on which curriculum has been framed than with the genre of the instructor. The extant practice of compartmentalization, of history, into Ancient, Medieval and Modern based on the political transitions is concatenated eluding similarly placed benchmarks like socio-economic and cultural advancements. Severance of history aligned with the rise and doom of dynasties have exclusive implications in India. The spirit of colonial historians 
like James Mill, who segmented the Indian history into Hindu, Muslim and Modern eras, still resides in the reeds of many historians, who have penned divisive histories dubbing Ancient Indian History as Hindu Period and Medieval Indian History as Muslim. The marauding of Turkish invasions in the north western parts of the country and establishment of a Turkish rule is pointed out to legitimate impressions of such nature and in attesting a tag of 'other or foreign' to certain religious communities. This colouring of history is appropriated by right wing movements to beef up their ranks. A transformation from this yardstick to either social or economic or cultural benchmarks would place pedagogy in a more comfortable and objective pedestal.

History since the empires has been used to legitimate footings- of either a person or a community. Our past perpetually shapes our existence. As in the case of books, occurrence of foregone are recorded in the collective memory of a society. As Romila Thapar remarked, the Public memory is hostage to selective amnesia. It has a penchant to be interpolated. These abrogated versions are transmitted to the subsequent generations and constitute a chunk of his comprehension. Pedagogy in history should be firm enough to erode this entrenched knowledge. The students should be enlightened on the ideological inclinations or latent schemes of the ones who mould and transmit this knowledge that is passed down to the successive generations. They should also be trained in the 'methodology' of the discipline as to interpret the past, its concrete and abstract facts and understand the context under which the knowledge under discussion was framed.

The tenacious proliferation of right-wing movements has disturbed both the steady progress of history writing and instruction. The volumes with the religious hue has overcompensated the wrongs committed by the colonial historians in addressing Indian history. History, in their hands, is being reduced as the sole doing of a particular religious or racial group and has been traced back to mythical past and cyclical occurrences. History has been used classically as an apparatus to aid the latent schemes of political organisations in legitimising their claims, aims and governance and cleave the coming generation into their bandwagons. In many instances, both at the union and the states, change in the party at helm has led to revision of school text books. These 'revised history' is more often 'indoctrinated' into innocent young minds. A version of the past is often advertised as 'the only version'. The tutor can bring a fundamental transformation by enlightening the students with different versions of the same instance of the past and place the 'only version' provided in the curriculum among these other versions. Such an innovation will lead the wards to comprehend the very nature of, multiplicity of viewpoints and "truth”, the discipline.

\section{Resolution}

As often pronounced, the mantle of a mentor in moulding the subsequent generations cannot be discounted. The appeal enjoyed by a teacher among his wards is unparalleled in its extend. This provides him with the unique convenience to forge each student according to his discretion. A pedagogue ought to be nonpartisan in the performance of his commitment. He should be prudent enough to keep at bay his ideological underpinnings and enrich the student with an objective understanding of the occurrence. The universal freedom handed over to the instructor to handle a lecture as he thinks it fit should be seized as an excuse to go beyond the decree of the syllabus and provide rich wisdom and acumen to the student in understanding and interpreting the discipline and how context and lurking schemes has perverted the art of writing history. This counsel fits well with instructors of all nomenclature, from primary school teachers to college and university professors. A pedagogue should be bound by the covenant of responsibility- both to the student and his profession and also by morality. His office should be performed without favouritism and should 
alone be fixated in enlightening the students with all the possible iridescent versions of the past occurrences, thus by preserving the faculties of a student from being tarnished by coloured versions.

\section{References}

[1] Carr, E H. (1961) What is History, Vintage Books, 3-35

[2] Beards, Andrew. (1997) Objectivity and Historical Understanding, Avebury, 110-122

[3] Haskell, L Thomas. (2000) Objectivity is not Neutrality, The John Hopkins University press, 145-174

[4] Chandra, Satish. (1996) Historiography, Religion and State in Medieval India, Har Anand,1-13 [5] Singh, Vipul. (2009) Interpreting Medieval India, Macmillan, 141-142 